\title{
MEASURING MODEL OF CONSUMER'S MORAL REASONING IN SPORT MARKETING: A SCALE DEVELOPMENT
}

\author{
Jasem Manouchehri, Ph.D. \\ (Corresponding Author) \\ Assistant Professor in Sport Management \\ Faculty of Physical Education and Sport Sciences \\ Central Tehran Branch, Islamic Azad University, Tehran, Iran \\ j.manouchehri@iauctb.ac.ir \\ Behzad Soheili, Ph.D. \\ Assistant Professor in Sport Management \\ Department of Physical Education and Sport Sciences \\ Malard Branch, Islamic Azad University, Tehran, Iran \\ behzad_soheily@iaumalard.ac.ir
}

\begin{abstract}
Objective of the study: The main goal of the present research was standardization of a model for measuring the amount of consumer moral reasoning in the face of moral scandal of sports celebrities.

Methodology: The participants of this research were all undergraduate students of physical education and sports sciences in universities of Iran, and a mixed method approach containing interviews with open questions as the qualitative phase and then confirmatory factor analysis as the quantitative phase were used to determine the validity of the research tools.

Originality: Endorser athlete's offenses are considered immoral. In view of moral psychology, moral feelings occur directly and automatically and moral reasoning is sought to create moral reasons. Moral reasoning is a situation in which individuals tend to choose information in the face of phenomena and try to get their moral result.

Main resuls: The findings showed that the validity and reliability of the measuring model, adapted to the qualitative findings, received acceptable values in comparison with reported values in other studies. The measuring model of moral reasoning components in the standard estimation, significant coefficients and obtained parameters from model showed good fit of the model.

Methodological contributions: The present study was limited to doping violation of endorser athletes and it is necessary that other violations that lead to negative propaganda and affect consumer moral reasoning, as an interesting study subject be considered by other researchers.

Managemnet contributions: Due to the often negative view toward doped athlete prior to moral reasoning, it is suggested that endorsement contracts be more stringent by companies and it seems more sensible to use celebrities from sports where the number of their positive doping tests is lower and there is little chance of such a violation. Ultimately considering the different perceptions of the sports community and the general population about doping or any violation, the study of the differences can be of interest to future researchers.
\end{abstract}

Keywords: Factor analysis. Marketing. Moral reasoning. Sport

\section{Cite como}

American Psychological Association (APA)

Manouchehri, J., \& Soheili, B. (2021, set./dez.). Measuring model of consumer's moral reasoning in sport marketing: a scale development. PODIUM Sport, Leisure and Tourism Review, São Paulo, 10(3), 52-83. https://doi.org/10.5585/podium.v10i3.17182. 


\section{MODELO DE MEDIÇÃO DO RACIOCÍNIO MORAL DO CONSUMIDOR EM MARKETING ESPORTIVO: UM DESENVOLVIMENTO DE ESCALA}

\section{Resumo}

Objetivo do estudo: O objetivo principal da presente pesquisa foi a padronização de um modelo para medir a quantidade de raciocínio moral do consumidor em face do escândalo moral de celebridades do esporte.

Metodologia: Os participantes desta pesquisa foram todos estudantes de graduação em educação física e ciências do esporte em universidades do Irã, e uma abordagem de método misto contendo entrevistas com questões abertas como fase qualitativa e, em seguida, análise fatorial confirmatória como fase quantitativa foram usados para determinar a validade de as ferramentas de pesquisa.

Originalidade: as ofensas do atleta endossante são consideradas imorais. Em vista da psicologia moral, os sentimentos morais ocorrem direta e automaticamente e o raciocínio moral é buscado para criar razões morais. O raciocínio moral é uma situação em que os indivíduos tendem a escolher informações diante dos fenômenos e tentar obter seu resultado moral.

Principais resultados: Os achados mostraram que a validade e confiabilidade do modelo de mensuração, adaptado aos achados qualitativos, recebeu valores aceitáveis em comparação com os valores relatados em outros estudos. O modelo de mensuração dos componentes do raciocínio moral na estimação padrão, coeficientes significativos e parâmetros obtidos do modelo mostraram bom ajuste do modelo.

Contribuições metodológicas: $\mathrm{O}$ presente estudo limitou-se à violação de doping de atletas endossantes e é necessário que outras violações que levem a propaganda negativa e afetem o raciocínio moral do consumidor, como interessante tema de estudo, sejam consideradas por outros pesquisadores.

Contribuições do managemnet: Devido à visão frequentemente negativa em relação ao atleta dopado antes do raciocínio moral, sugere-se que os contratos de endosso sejam mais rigorosos por parte das empresas e parece mais sensato usar celebridades de esportes onde o número de seus testes de doping positivos é menor e há pouca chance de tal violação. Em última análise, considerando as diferentes percepções da comunidade esportiva e da população em geral sobre o doping ou qualquer violação, o estudo das diferenças pode ser de interesse para futuros pesquisadores.

Palavras-chave: Análise fatorial. Marketing. Raciocínio moral. Esporte

\section{MODELO DE MEDICIÓN DEL RAZONAMIENTO MORAL DEL CONSUMIDOR EN EL MARKETING DEPORTIVO: UN DESARROLLO A ESCALA}

\section{Resumen}

Objetivo del estudio: El objetivo principal de la presente investigación fue la estandarización de un modelo para medir la cantidad de razonamiento moral del consumidor frente al escándalo moral de las celebridades deportivas.

Metodología: Los participantes de esta investigación fueron todos estudiantes de pregrado de educación física y ciencias del deporte en universidades de Irán, y se utilizó un enfoque de método mixto que contiene entrevistas con preguntas abiertas como fase cualitativa y luego análisis factorial confirmatorio como fase cuantitativa para determinar la validez de las herramientas de investigación.

Originalidad: las infracciones de los deportistas patrocinadores se consideran inmorales. En vista de la psicología moral, los sentimientos morales ocurren directa y automáticamente y se busca el razonamiento moral para crear razones morales. El razonamiento moral es una situación en la que los individuos tienden a elegir la información frente a los fenómenos y tratan de obtener su resultado moral.

Resultados principales: Los hallazgos mostraron que la validez y confiabilidad del modelo de medición, adaptado a los hallazgos cualitativos, recibió valores aceptables en comparación con los valores reportados en otros estudios. El modelo de medición de los componentes del razonamiento moral en la estimación estándar, los coeficientes significativos y los parámetros obtenidos del modelo mostraron un buen ajuste del modelo.

Aportes metodológicos: El presente estudio se limitó a la infracción por dopaje de deportistas endosantes y es necesario que otras infracciones que conduzcan a la propaganda negativa y afecten el razonamiento moral del consumidor, como tema de estudio interesante, sean consideradas por otros investigadores. 
Contribuciones de managemnet: Debido a la opinión a menudo negativa hacia los atletas dopados antes del razonamiento moral, se sugiere que los contratos de patrocinio sean más estrictos por parte de las empresas y parece más sensato usar celebridades de deportes donde el número de sus pruebas de dopaje positivas es menor y hay pocas posibilidades. de tal violación. En última instancia, considerando las diferentes percepciones de la comunidad deportiva y la población en general sobre el dopaje o cualquier violación, el estudio de las diferencias puede ser de interés para futuros investigadores.

Palabras clave: Análisis factorial. Marketing. Razonamiento moral. Deporte.

\section{Introduction}

Marketing is an issue that more than any other business, dealing with customers. Probably the simplest marketing definition is that: Marketing means managing beneficial relationships with customer. One of the two-way marketing goals is to attract new customers by promising more value, and the other is to maintain and grow current customers with satisfaction (Kotler \& Armstrong, 2012). Also, the term of marketing refers to the use of advertising, personal and general sales methods to raise awareness of a product or attract more customers to buy goods and services of teams and brands and to be presented in their events (Soheili and Manouchehri, 2020). Meanwhile, the use of athlete's celebrities to endorse marketing acts is common which can lead to corporate profits, as well as numerous positive, negative, and neutral reactions of consumers. But on the other hand, there is the possibility of committing those endorsers to immoral acts, including doping, which will result in numerous positive, negative, and neutral reactions from consumers. Doping may come from the high priority for winning at al cost, however, findings of Barkoukis, et a. (2016) indicated that Health is ranked as the most important value of sport, and doping use is ranked as the most important threat to the integrity of sport in the intervention group. The doping phenomenon refers exclusively to the use of performance enhancing methods and substances in sport competition in order to improve or maintain performance and also avoid the process of drug sampling (Manouchehri and Tojari, 2014). The organized drug testing in the Olympics backs to the Mexico City in 1968. Although there is a global mutual believe on fighting against doping in sport, particularly, athletes who need the testing system to be effective and to function well across the world show greater distrust of or dissatisfaction with the current testing system. The athletes' diverging views indicate that contemporary anti-doping policy is simultaneously met with support, (dis)trust and frustration (Overbye, 2016). 
Manouchehri, J., \& Soheili, B. (2021, set./dez.). Measuring model of consumer's moral reasoning in sport marketing: a scale development

The immoral performance of endorser athletes occurred unexpectedly and marketers have little control to prevent it. Copeland and Potwarka (2021) emphasized on the role that individual cognitive antecedents and contextual organizational factors (i.e., policies, leadership, ethical climate, and infrastructure) play in ethical decision-making processes. Many objective examples (e.g., Kobe Bryant, Tiger Woods, Lance Armstrong, and Ray Rice) have shown how the endorser athlete's image is vulnerable to sports consumers when the negative advertisement will lead to controversy. As noted above, such improper behaviors create managerial problems associated with continuing or not cooperating with endorser athletics who commit scandals for brand managers. However, today, there are a few empirical researches in the field of sports' consumer in response to violations of famous athlete and its effect on related brands. Therefore, there is little evidence to explain that an endorsed brand should continue its relationship with an endorser committed to immoral acts or not continue its relationship (Manouchehri, 2021; Manouchehri, et al., 2021).

In addition, most of the studies related to the scandal of the athlete suggest that consumer's perception of athlete's offense by linking an athlete with immoral acts to brands has a negative impact on endorser/brand evaluations. For example, people tend to judge a famous person committing immoral acts based on two judgments: in general, "good" or "bad". This two-sided superficial view may have prevented a deep understanding related to how to process negative events about athlete's endorsement to the consumer for researchers. This two-side view only allows for a limited prediction of consumer reactions to the violation and its potential effects on the attitudinal and behavioral outcomes. This approach does not go into the question of what causes consumers to judge offenders and their related brands, but it simply compares perceptual consequences. As it emanates from the research findings, this approach also limits our understanding of processing negative information by consumers about a scandal. As a result, the community has gained a little understanding of how different reasoning processes of consumers can explain multifaceted responses to the athlete's offenses (Manouchehri, 2021).

Also, when a consumer becomes interested in a particular marketing entity (e.g., company or brand) and engages in unethical behavior, he or she may reinterpret the behavior to make it appear ethical with "Moral Rationalization" or with "Moral Decoupling" separates performance from morality (Bhattacharjee, Berman \& Reed, 2013). The high level of moral decoupling has shown a higher level of significance of trust and attitudes towards the endorser (Hur, et al., 2018). 
Moral reasoning is a situation in which individuals tend to choose information in the face of phenomena and try to get their moral result (Bhattacharjee, Berman and Reed, 2013). According to Bhattacharjee, Berman \& Reed (2013), the moral reasoning has three components as follows. Moral decoupling: moral decoupling is psychological separation process by which consumers selectively dissociate judgments of morality from judgments of performance. Moral rationalization: moral rationalization is the process of reconstructing immoral actions as less immoral in order to maintain support for an immoral actor. Moral coupling: moral coupling is a process that allows consumers to integrate judgments of performance and judgments of morality. Though, the recent study (Bhattacharjee, Berman \& Reed, 2013) expanded moral reasoning processes in connection with other people's immoral actions. That study specifically acknowledged that consumers often consider immoral judgments of public figures as unrelated to judgments of job performance (which is called moral decoupling) when attention to their violations. This issue for explaining how people simultaneously support publicly-staggered images with two types of conflicting perceptions (Positive for negative judgment against negative for moral judgment) provides a proper theoretical framework.

On the other hand, Newman and Brucks (2018) examined the effect of the brand's previous social responsible behavior on current consumer behavior. Findings showed that the extent to which consumers of brand design integrate their brand overlap in their design, affects the impact of the brand's previous social responsible behavior on consumer behavior. Consumers with a high level of brand identity are more likely to engage in balancing their behavior with brand behavior in which the brand has a high (low) level of social responsibility, as well as a high consumer identity to the brand, leads to less (more) generous and more (less) cheating. In other words, in high-identity consumers, the ethical behavior of the brand can serve as a license for immoral consumer behavior. More importantly, the effect of moral authorization is adjusted when the consumer becomes aware of his or her ethical behavior. It is therefore believed that the focus on more details of these analyzes should continue. When assessing stability and continuity, it is important to consider the mechanism by which consumers are able to change the relationship between the two ethically related aspects. For example, as the findings of Bhattacharjee, Berman \& Reed (2013) show, a consumer may react differently when he or she separates a company's ethical behavior from the quality of its desired product as long as they measure moral behavior towards it (Paharia, Vohs \& Deshpande, 2013). 
Nevertheless, there is still a phenomenon that has not been described moral decoupling (e.g., moral decoupling and moral rationalization) by the framework of previous moral reasoning. For example, despite the fact that some people tend have a separate judgment, the available evidence suggests that some people are willing to integrate judgments. In other words, they combine moral and perfomance judgment when confronted with a famous athlete's offense. For example, some people still condemn Michael Wick, the offensive line football player who was accused of promoting dogfighting, with phrases such as "he is not a great football player", and "he is an immoral animal...". NFL should not be allowed him to return (Perron, 2009). This example about Michael Vick reflects a reasoning strategy that is distinctly different from moral decoupling and Moral reasoning. This means that individuals may combine judgments when evaluating and processing negative information about athletes.

A number of other methods of Moral Rationalization that use moral reasoning, such as moral disengagement (e.g., Bandura, et al., 1996), may occur in both individuals and organizations. In addition, studies should apply generalized stability to moral sentiment (Manouchehri, 2019) and values that consumers may take in action against a company that conflicts with their ethical values or engage in certain moral behaviors to avoid experiencing negative moral feelings. Understanding the factors influencing consumers' choices in regulating personal interests is important for improving social behavior (for example, factors that influence a consumer's decision to donate to a charity or fraudulent behavior to gain benefits). Factors that influence a consumer's ethical choice can be internal (e.g., individual differences that are inconsistent with all consumers) or external (related to marketer or position). Individual factors that affect the power of consumers 'ethical responses, and a psychological understanding of consumer market ethics, require an understanding of the factors influencing consumers' ethical responses in market exchanges. As mentioned earlier, there are a variety of ethical responses that include emotions, values, judgments, and behaviors (Newman and Brucks, 2018).

Endorser athlete's offenses are considered immoral not only for those who have a deep emotional attachment to the athlete, but also to other consumers who are indifferent to them. In view of moral psychology, moral judgments arise through relatively automatic intuitive processes, and moral reasoning processes are employed post hoc to construct reasons that support the intuitive judgment (Haidt 2001). Also, according to Kunda (1990) individuals are motivated to selectively search for information and reach a desired self-serving moral conclusion. The body of literature, including the research by Bhattacharjee, Berman \& Reed (2013) with a focus on moral decoupling, and Bandura, et al. (1996) with a focus on moral 
rationalization has provided a useful theoretical framework for describing the mechanisms of moral reasoning of individuals. In particular, this literature suggests that cognitive dissonance in individuals motivate them to activate their moral reasoning strategies.

Therefore, considering the importance of understanding the diverse range of consumer behaviors and his various moral reasoning after the occurrence of an immoral act by the endorser (for example, doping) and given that most of the published findings have focused on understanding the factors influencing the (un)ethical behaviors of endorsers or consumers and the resulting behavioral responses, The need for a standard measurement tool to benefit from studies related to moral reasoning arising from consumer cognitive dissonance is felt. Consumer behaviors, however, include positive and negative choices and actions, responses to immoral actions, and even those that are morally questionable and it is not clear whether they are right or wrong (Von Schuckmann, et al., 2018). In this way, the currect paper provided an instrument for focousing on doping scandal by endorsers which is one of the most repetitive problems existed in elite sport. Additionally, as there may be different conception about doping by diverse range of costumers, specific points of view came from physical education and sport sciences students can provide a better generalizability of the results to this community to enable reaserchers and managers having deeper understaning of this phenomenon and its impact on sales and behavioral outcomes. On the other hand, emergeing and developing endorsements activities in Iran in just recent decade can be considered as the most notable reason behind the neglecting this field of study (scandal by endorsers). Moreover, among many related others, this research is the only to try developing this knowledge separately aiming to represent a measurement model of the moral reasoning strategies after any level of cognitive dissonance coming from endorser's doping scandal. It is also worth to declare that the importance of realizing constumers' probable and future responses to a scandal may lead both researchers and managers to utilize the ficticious cenario and the items in this scale in their surveys among the costumers befor any contract signing with sport celebrity endorsers.

Therefore, the main purpose of the present research was to provide a model for measuring the level of consumer moral reasoning in the face of moral scandal of celebrities sports endorsement that the researchers, by developing the tool and its items that have been used in previous studies, have sought to standardize the scale of moral reasoning strategies to help future researchers and strengthen the necessary theoretical foundations in this regard. 
Manouchehri, J., \& Soheili, B. (2021, set./dez.). Measuring model of consumer's moral reasoning in sport marketing: a scale development

\section{Methodology}

Some individuals seek to discuss the value or yield of mixed methods research and how and in what way it provides better findings about the research problems than using either qualitative or quantitative approaches alone. we considered mixed methodology because it utilizes qualitative and quantitative approaches in one or more of the following ways: two types of research questions (qualitative and quantitative approaches), the manner in which the research questions are developed (participatory and preplanned), two types of sampling procedures (probability and purposive), two types of data collection procedures (surveys and in-depth interviews), two types of data (numerical and textual), two types of data analysis (statistical and thematic), and two types of conclusions (objective and subjective) (Tashakkori and Creswell, 2007; Clark and Creswell, 2008).

Therefore, the present study is a mixed method and is a type of exploratory mixed research projects. On the other hand, types of research can be distinguished based on three criteria of outcome, purpose, and data type. Therefore, based on this, the type of research from the perspective of the objective has been exploratory and explicit in the first and second phase respectively. From the perspective of the result, in both stages has been developmental and also in terms of data, in first stage has been qualitative and in the second stage quantitative.

\section{Research tools}

The tools used to collect qualitative and quantitative data are as follows:

\section{- Qualitative research section}

In the qualitative section of the research, general and open ended questions taken from the bogus scenario associated with doping scandal of a person named Babak (a fictitious person) as an imagined person who did not exist and was asked the interviewees. During the interviews, for better understanding of the phenomenon, more detailed questions of interviewers were asked and their statements were noted and recorded.

\section{- Quantitative research section}

Questions package of quantitative section were including 4 parts. The first part of the demographic question included age, gender, marital status, sport record, championship record, coaching history and sports. The second part presented a brief description of how to answer the 
questionnaire questions. The third part of the questions package included a bogus scenario about a person called Babak (a fictitious person) and his doping scandal. The fourth part of the questions package was also a questionnaire related to the bogus scenario, which included the moral reasoning strategies (Bhattacharjee, Berman \& Reed, 2013).

- Scale of moral reasoning strategies (Bhattacharjee, Berman \& Reed, 2013):

Scale of moral reasoning strategies measures the method of selecting information and trying to deduce the consumer's moral conclusions in dealing with the doping phenomenon. The scale of moral reasoning strategies consisted of 10 statements that were adjusted to the Likert 7-point response scale from strongly disagree to strongly agree $(1=$ strongly disagree, 7 $=$ strongly agree). This scale has three subscales including moral decoupling (questions 1-3 of the questionnaire), moral rationalization (questions 4-8 of the questionnaire) and moral coupling (Questions 9 and 10 of the questionnaire). There was evidence of the validity and reliability of the previous use of the scale (0.920) with Cronbach's alpha (Bhattacharjee, Berman \& Reed, 2013). In the present study, Cronbach's Alpha was obtained for moral dicoupling (0.842), moral rationalization (0.886) and moral coupling (0.749).

\section{Statistical population and research participants}

The statistical population of the present study on implementation of qualitative interviews and also distribution of quantitative questionnaires including all undergraduate students in physical education and sports sciences in the universities of Iran.

According to the theoretical basis of qualitative researches, the theoretical sampling method was used for sampling. Therefore, after interviewing the 12th person, repeated information was obtained that led to the interruption of interviews and theoretical saturation in the eighteenth interview. Nine male interviewees and nine interviewed women participated in this study.

After setting up quantitative questionnaires, using analyzed qualitative data and available standard tools, 10 items were considered for measuring the variables of the research and 224 men and women in the quantitative section of research answered closed questionnaire to test the research measuring model. 
Manouchehri, J., \& Soheili, B. (2021, set./dez.). Measuring model of consumer's moral reasoning in sport marketing: a scale development

\section{Data analysis method}

- Qualitative section of research:

In the qualitative part of the research, data analysis was done by logical induction in order to conceptualize and theorize. The process of data analysis was as follows: 1) Implementing and editing interviews, 2) coding comments, 3) Classification of opinions in the same conceptual groups, 4) interpreting the concepts derived from the research, 5) combining concepts and conclusions, and 6) comparing the results with results of other researches.

\section{- Quantitative section of research}

Confirmatory factor analysis was used to determine the validity of the research tools because doing that was essential for normalization in the statistical society of the test, and the researchers tried to implement it. Also, descriptive statistics were used to summarize and categorize raw data and calculate the mean, frequency, standard deviation and drawing tables. Cronbach's alpha test was used to calculate the reliability of the tools. The data was analyzed using SPSS 23 and LISREL 8.8.

\section{Results}

\section{Qualitative findings}

- Description of Demographics of the Interviewees

Findings of qualitative data analysis showed that out of the total number of interviewees, $28 \%$ were active in ball sports, $28 \%$ in bodybuilding, $39 \%$ in martial arts, and $5 \%$ in swimming. Findings also showed that $16.5 \%$ of the total interviewees had less than 5 years of sports experience, $28 \%$ had 6 to 10 years of sports experience, $39 \%$ had 11 to 14 years of sports experience, and $16.5 \%$ had more than 15 years of sports experience.

Findings of qualitative data analysis showed that out of the total number of interviewees, $50 \%$ had amateur coaching records, 33.5\% had regional championship records, and $16.5 \%$ had national championship records. The results also showed that $33.5 \%$ of the interviewees were less than 25 years old, $28 \%$ were 26 to 30 years old, $22 \%$ were 31 to 35 years old, and $16.5 \%$ were more than 36 years old. In addition, the findings showed that in total, an equal number of male and female interviewees (50\%) participated in the interview.

\section{- Qualitative Data Analysis}


The steps of analyzing the qualitative data of the research were presented in the form of three coding steps.

\section{Step 1: Open coding}

The first step involves three steps: extracting data from the interview text, coding, and discovering categories.

There are two ways to extract data from interviews; Microanalysis and Key Points Analysis. Strauss and Corbin (1992) recommend that coding be done through microanalysis. In this type of analysis, the data is analyzed word by word and the meanings found in the words or groups of words are encoded. This method has two drawbacks; the first is that it is time consuming and the second is that it sometimes leads to ambiguity and confusion. In addition, sometimes the division of data into words leads to the contamination of the soul of analysis and there is a kind of doubt about what should be searched in the text (Danaeifar, Alvani, Azar, 2013).

Another method proposed by Glaser (1992) is key point coding. In this method, instead of coding individual words, key points are identified and coded.

In this study, first the content of all interviews was implemented and then their open coding was done by key point coding method. In this way, the data collected in the interviews were written down on paper, and then open source code was generated by line-by-line and paragraph-by-paragraph analysis.

As an example of open coding, an interview with one of the subjects is presented. In total, 137 open source codes were obtained from the analysis of 18 interviews (Table 1).

\section{Step 2: Axial coding}

Axial coding is the second stage of analysis in foundation data theorizing. The purpose of this step is to establish a relationship between the generated classes (in the open coding stage). This operation is done based on the paradigm model and helps the theorist to facilitate the process of creating a theory (Danaeifar, Alvani, Azar, 2013).

In axial coding, the codes generated in the previous step were rewritten in a new way with the aim of making connections between the codes. Axial coding leads to the creation of groups and categories; all similar codes were placed in their own group. For this purpose, all 
Manouchehri, J., \& Soheili, B. (2021, set./dez.). Measuring model of consumer's moral reasoning in sport marketing: a scale development

the generated code was reviewed and compared with the texts so that the content would not be forgotten. In this process, several open codes could be encoded as an axial code. 137 extracted open codes were converted to 86 axial codes (Table 1).

Table 1

An Example of Open and Axial Coding in this Research

\begin{tabular}{|c|c|c|c|}
\hline Marker & Interview Text (Key Points) & Open Coding & $\begin{array}{l}\text { Axial } \\
\text { Coding }\end{array}$ \\
\hline P601 & $\begin{array}{l}\text { The community will definitely look at them } \\
\text { negatively }\end{array}$ & $\begin{array}{l}\text { Negative image of } \\
\text { doped athlete in public }\end{array}$ & $\begin{array}{l}\text { Doped athlete bad } \\
\text { image }\end{array}$ \\
\hline P602 & $\begin{array}{l}\text { In my opinion, it has destroyed not only its } \\
\text { own image but also the image of the } \\
\text { country's sports }\end{array}$ & $\begin{array}{l}\text { Destructive image } \\
\text { compared to others }\end{array}$ & $\begin{array}{l}\text { Bad image } \\
\text { towards others }\end{array}$ \\
\hline P603 & $\begin{array}{l}\text { Doping is always a topic of discussion and } \\
\text { is considered immoral in sports. I also do } \\
\text { not consider doping permissible and I wish } \\
\text { that athlete did not do that }\end{array}$ & Opposition to doping & \multirow{2}{*}{$\begin{array}{l}\text { Opposition to } \\
\text { doping and doped } \\
\text { athlete }\end{array}$} \\
\hline P604 & $\begin{array}{l}\text { If he did not do this, my feelings would not } \\
\text { have changed. I do not tolerate and accept } \\
\text { this athlete's offense because he has been } \\
\text { looking for cheating and extra power. }\end{array}$ & $\begin{array}{l}\text { Feeling uncomfortable } \\
\text { of doped athlete }\end{array}$ & \\
\hline P605 & $\begin{array}{l}\text { Anyway, I have raised the flag of the } \\
\text { country and I am a fan of it, and its success } \\
\text { is important to me because it has won } \\
\text { medals. }\end{array}$ & To be fan after doping & \multirow[t]{2}{*}{ Non-commitment } \\
\hline P606 & $\begin{array}{l}\text { I have no obligation, because he made a } \\
\text { mistake }\end{array}$ & $\begin{array}{l}\text { Lack of commitment } \\
\text { to the doped athlete }\end{array}$ & \\
\hline P607 & $\begin{array}{l}\text { I think it will have a negative effect on the } \\
\text { evaluation. Of course, I also ask the reason } \\
\text { for committing doping to see if he did it } \\
\text { himself or was under pressure. }\end{array}$ & $\begin{array}{l}\text { The Negative Impact } \\
\text { of Doping on Ethical } \\
\text { Evaluation }\end{array}$ & \multirow{2}{*}{$\begin{array}{l}\text { Negative impact } \\
\text { on moral } \\
\text { evaluation }\end{array}$} \\
\hline P608 & $\begin{array}{l}\text { It has a negative effect on people's } \\
\text { evaluation, and it should be so. It has a }\end{array}$ & $\begin{array}{l}\text { negative effect on the } \\
\text { moral evaluation of the } \\
\text { masses }\end{array}$ & \\
\hline P609 & $\begin{array}{l}\text { I think the discussion is separate. In every } \\
\text { part of life, we have both good and bad } \\
\text { things. In sports, doping is bad, but in } \\
\text { general, social violations are more harmful, } \\
\text { but in general, both are wrong, but they are } \\
\text { different. }\end{array}$ & $\begin{array}{l}\text { The insignificance of } \\
\text { doping offenses in the } \\
\text { community }\end{array}$ & $\begin{array}{l}\text { The low } \\
\text { importance of } \\
\text { doping in society }\end{array}$ \\
\hline
\end{tabular}

Source: Authors 
Manouchehri, J., \& Soheili, B. (2021, set./dez.). Measuring model of consumer's moral reasoning in sport marketing: a scale development

\section{Step 3: Selective coding}

Once all the data has been coded as mentioned, it is time to group them; In fact, the goal of fundamental theorizing is to produce theory, not just to describe a phenomenon. To turn analysis into theory, classes must be related to each other on a regular basis. Selective coding based on the results of the previous two stages of coding is the main stage of theorizing. In this way, it systematically relates the axial class to other classes and presents those relations within the framework of a narrative and modifies the classes that need further improvement and development (Danaeifar, Alvani, Azar, 2013).

In the code grouping, the axial codes extracted from the interviews were grouped and then the groups created were compared with each other to identify and extract the main groups and dimensions of each. Of course, at this stage, referring to the theoretical literature of the research helped a lot to make the groupings more accurate. In this research, based on the researchers' understanding of the text of the studied phenomenon, i.e. the moral reasoning resulting from cognitive dissonance, the framework of the paradigm model was shown in a narrative form.

Grouping the axial codes in each case and comparing them showed that all the obtained codes can be placed in the three main groups of moral coupling, moral decoupling and moral rationalization.

Based on the analysis of the interviews using the theory method derived from the data, the components of moral reasoning (cognitive dissonance) are as follows (Table 2).

\section{Moral coupling:}

The ominous phenomenon of doping is hated and intolerable for most people. Drug use is considered not only a significant threat to the health of athletes as well as the value and nature of sports, but also many sports organizations consider it as the most important ethical and health challenge in sports (Houlihan, 2002). For this reason, all interviewees were opposed to this phenomenon, and a large group of them also condemned doping and doped athlete because of the belief that the immorality of the athlete mentioned in the scenario and his endorsement and the product are related to each other and they stopped consuming the desired product. Therefore, the moral coupling can be considered as a complete connection between the doped athlete and 
his endorsement actions, which also had a direct and destructive effect on the behavioral consequences of the consumer.

\section{Moral decoupling:}

Bhattacharjee, Berman \& Reed (2013) describe moral decoupling as "the process of psychological separation in which consumers selectively distinguish between moral judgments and performance judgments" (p. 1168). Regarding the endorsement of the famous doped athlete, the interviewees who were opposed to doping but were interested in their athlete acknowledged that there was no connection between the endorsed product and the athlete's doping and that the two should not be linked. In fact, the cognitive dissonance created in their negative attitude towards doping and their purchasing behavior that supports the product led to an argument that there was no link between the products and endorsed doping. In other words, it was thought that doping and negative attitudes towards it could lead to negative consequences in consumer behavior, in which moral decoupling in the consumer, and in the opinion of the interviewees in particular, played a moderating role.

\section{Moral rationalization:}

According to Bhattacharjee, Berman \& Reed (2013), moral rationalization is a "process of reconstructing immoral actions in a less immoral way in order to maintain the protection of the immoral perpetrator" (p. 1168). A group of interviewees who were interested in the offending athlete mentioned in the scenario also acknowledged that doping is not a very important crime in society and that there are riskier and more harmful crimes in society. Therefore, it seems that the interest and support as well as the commitment to the athlete lead to the moral rationalization of doping in sports and society, and the athlete who commits it is not considered an important and great criminal. Regarding his endorsement and the negative publicity that can be adversely affected by the behavioral consequences of the sports consumer, moral rationalization is an argument that plays a moderating role and reduces the harmful effects of athlete misconduct on word-of-mouth marketing, purchase intent, and brand loyalty. 
Manouchehri, J., \& Soheili, B. (2021, set./dez.). Measuring model of consumer's moral reasoning in sport marketing: a scale development

Table 2

Main and Sub Groups, and Axial Codes Extracted from all Interviews

\begin{tabular}{|c|c|c|}
\hline Main Group & Subgroup & Axial Codes \\
\hline \multirow{6}{*}{$\begin{array}{c}\text { Moral } \\
\text { Reasoning }\end{array}$} & \multirow{2}{*}{ Moral Coupling } & Opposition to doping and doped athlete \\
\hline & & Negative impact on moral evaluation \\
\hline & \multirow[t]{2}{*}{ Moral Decoupling } & $\begin{array}{l}\text { No connection between the product and the } \\
\text { endorser }\end{array}$ \\
\hline & & $\begin{array}{l}\text { No difference between doping and other } \\
\text { functional tools }\end{array}$ \\
\hline & \multirow[t]{2}{*}{ Moral Rationalization } & Low importance of doping In the society \\
\hline & & $\begin{array}{c}\text { Existence of more serious violations in the } \\
\text { society }\end{array}$ \\
\hline
\end{tabular}

Source: Authors.

\section{Quantitative findings}

Demographic findings

In this section of the statistical analysis, we analyze the distribution of the statistical sample in terms of variables such as gender, age and sport history. Of the total 224 respondents who answered the research questions and their information is available, 121 (54\%) were men and $103(46 \%)$ were female. Among the sample subjects, 57 people were from 18 to 23 years old (25.4\%), 80 people were from 24 to 29 years old (about 35.7\%), 53 people were from 30 to 35 years old (about $23.7 \%$ ) And 34 people were more than 36 years old (about 15.2\%). Amonge the sample ofe the research 41 people had a history of exercise less than 3 years old (about $18.3 \%$ ), 60 people had a history of exercise from 4 to 8 years (about 26.8\%), 53 people had a history of exercise from 9 to 14 years (about 23.7\%), And 70 people had a history of exercise more than 15 years (about $31.2 \%$ ) in sport.

\section{Descriptive findings of the research variables}

In the following we discuss the descriptive parameters such as mean and standard deviation for all the research variables in terms of statistical sample population. For example, as Table 3 shows, the score of the components of moral reasoning is in the range of 1 to 7 and 
Manouchehri, J., \& Soheili, B. (2021, set./dez.). Measuring model of consumer's moral reasoning in sport marketing: a scale development

their mean values are close to 4 or higher that shows moral reasoning (moral decoupling, moral rationallization, and moral coupling) is relatively high in the present research.

Table 3

The Survey of Descriptive Statistics of Research Variables

\begin{tabular}{ccccccc}
\hline Variable & Component & Symbol & Min. & Max. & Mean & $\begin{array}{c}\text { Standard } \\
\text { Deviation }\end{array}$ \\
\hline Moral Reasoning & $\begin{array}{c}\text { Moral Coupling } \\
\text { Moral } \\
\text { Rationallization }\end{array}$ & MD & 1.00 & 7.00 & 4.79 & 1.66 \\
& Moral Decoupling & MC & 1.00 & 7.00 & 3.94 & 1.36 \\
& & & & 7.00 & 4.83 & 1.30 \\
\hline
\end{tabular}

Source: Authors

\section{Reliability testing of the research tool}

Cronbach's alpha coefficients were found to be very suitable for the research variables, the highest coefficient for the moral decoupling (0.842) and the lowest for the moral coupling variable (0.749). The coefficient for the moral rationallization variable was also obtained 0.842 .

\section{Factor analysis of moral reasoning variable}

In the present research, as mentioned earlier, moral reasoning includes moral decopling, moral rationallization, and moral coupling, which in total constitute the components of moral reasoning.

Figure 1 and Table 4 shows the findings of the model of measuring the components of moral reasoning in the standard estimation, significant coefficients and obtained parameters of the model. Model factor loads in the standard estimation mode show the impact of each of the variables or clauses in explaining the variance of the variables or main factors. According to Figure 1 and Table 4, we can see the factor loads of each research question. For example, the factor load of the first question in the moral decoupling dimension (MD1) is 0.77. In other words, the first question explains approximately $59 \%$ of the variance of moral decoupling. The error rate is also 0.40 (The amount of variance that can not be explained by the first question, it is clear that the lower the error rate, there is the higher determination coefficients and the greater correlation between the question and the relevant factor). The determination coefficient is a number between 0 and 1 and as soon as it approaches 1 , the value of the detection of variance is increased. Also, meaningful test values greater than 1.96 or less than 1.96 represent the significance of relationships. The basis of confirmation or rejection of meaningful 
Manouchehri, J., \& Soheili, B. (2021, set./dez.). Measuring model of consumer's moral reasoning in sport marketing: a scale development

relationships between each subscale and its items is review the model in the state of significant coefficients. At the error level of 0.05 and the two-way test (normal default), the critical values of the numbers are 1.96 and -1.96 . If significant coefficients be greater than 1.96 or smaller than -1.96 , null hypothesis will be rejected and alternative hypothesis That is, the existence of a meaningful relationship will be confirmed. All relations in the model (one-way arrows) are a simple regression equation, and their significance should be investigated.

\section{Figure 1}

Measuring Model of the Research in Standard Estimates

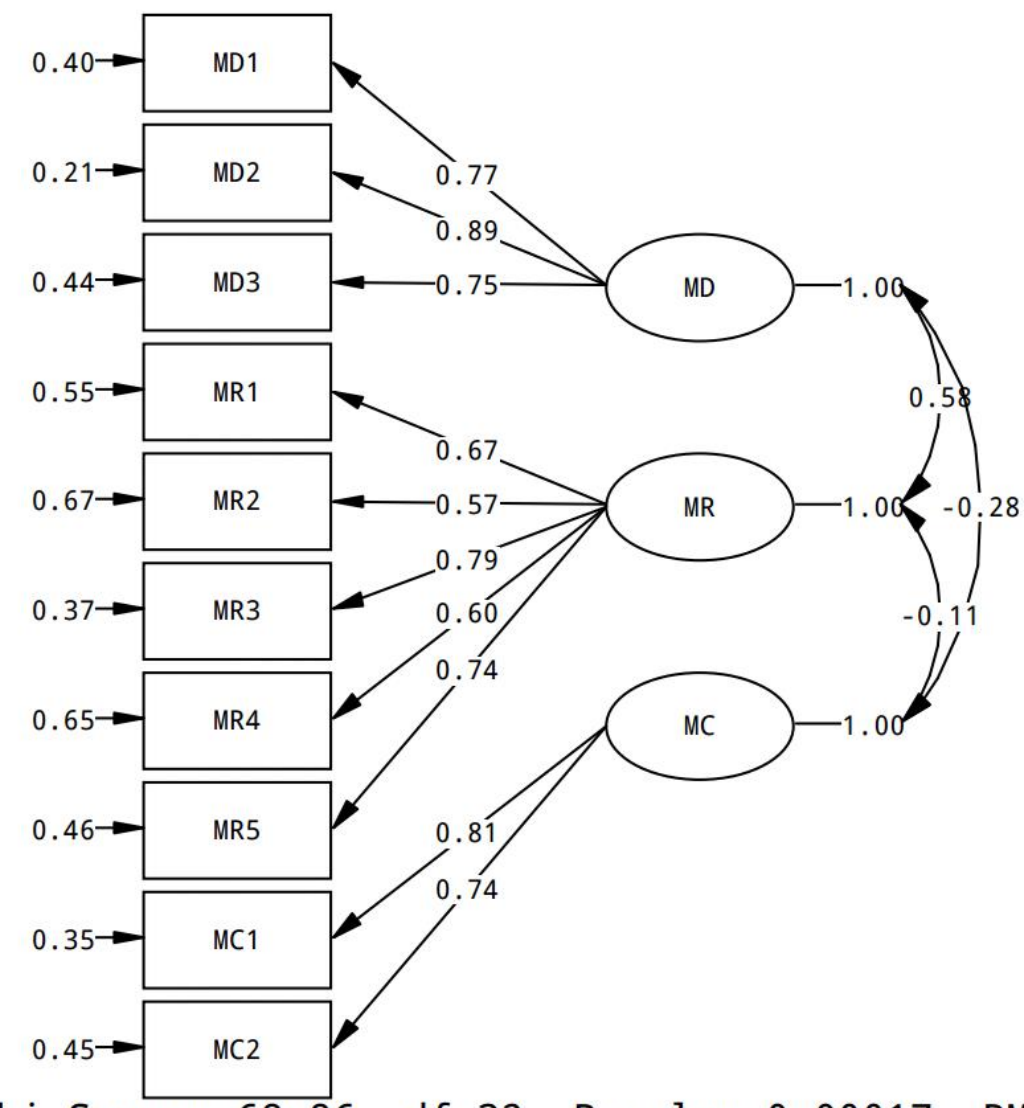

Chi-Square=68.86, $d f=32, P$-value $=0.00017$, RMSEA $=0.072$

Source: Authors. 


\section{Table 4}

The Results of Measuring Model of Moral Reasoning

\begin{tabular}{|c|c|c|c|c|c|c|}
\hline Item & & & $\begin{array}{c}\text { Factorial } \\
\text { load }\end{array}$ & Error & Variance & $\begin{array}{c}\text { Significance } \\
\text { Coefficient }\end{array}$ \\
\hline Babak's violation does not change my assessment of his technical performance. (MD1) & $\longrightarrow$ & MD & 0.77 & 0.40 & 0.60 & 12.82 \\
\hline Judgments of Babak's technical performance should be separate from his moral judgment. (MD2) & $\rightarrow$ & MD & 0.89 & 0.21 & 0.79 & 15.53 \\
\hline Reports of offenses should not change our vision of Babak's successes. (MD3) & $\longrightarrow$ & MD & 0.75 & 0.44 & 0.56 & 12.25 \\
\hline Babak's violation is not as bad as other social offenses. (MR1) & $\longrightarrow$ & MR & 0.67 & 0.55 & 0.45 & 10.40 \\
\hline In the case of Babak's humiliation by society, his doping violation is a good behavior. (MR2) & & MR & 0.57 & 0.67 & 0.33 & 8.62 \\
\hline It is important to keep in mind that the athlete's action is actually not very harmful. (MR3) & $\rightarrow$ & MR & 0.79 & 0.37 & 0.63 & 12.99 \\
\hline It is unfair to blame Babak alone, because his surrounding people are also guilty. (MR4) & $\longrightarrow$ & MR & 0.60 & 0.65 & 0.35 & 9.01 \\
\hline Babak should not be considered guilty, because the pressure of modern sports is very high today. (MR5) & $\longrightarrow$ & MR & 0.74 & 0.46 & 0.54 & 11.79 \\
\hline The people's perception of Babak's violation should affect the assessment on his performance. (MC1) & $\longrightarrow$ & $\mathrm{MC}$ & 0.81 & 0.35 & 0.65 & 6.27 \\
\hline When evaluating Babak's technical performance, it's important to consider his offenses. (MC2) & $\longrightarrow$ & $\mathrm{MC}$ & 0.74 & 0.45 & 0.55 & 6.12 \\
\hline
\end{tabular}

[MD= Moral Decoupling, MR= Moral Rationalization, MC= Moral Coupling].

Source: Authors. 
The estimation results in the model of moral reasoning factors indicate the relative suitability of the indices. According to the LISRELOutput, the calculated $\chi 2$ is equal to 68.86 , which in relative to the degree of freedom $(\mathrm{df}=32)$ is less than $3\left(\chi^{2} / \mathrm{df}\right.$ is equal to 2.15$)$. RMSEA value is equal to 0.072. Allowance limit for RMSEA is 0.1. The GFI, AGFI and NFI indices are $0.90,0.90$ and 0.94 respectively, indicating a very good fit.

As Table 5 shows, firstly, all factor loads are greater than 0.5 and, secondly, the average variance extracted (AVE) in the variables of moral decoupling and moral coupling is greater than 0.5, which indicates convergent type of validity (Chin, 1998; Straub, 1989). Also, average variance extracted (AVE) in all variables is greater than the square of the correlation between each two of them, which indicates discriminant type of validity (Chin, 1998). The composite reliability $(\mathrm{CR})$ in all variables is also greater than 0.7 , which indicates composite type of reliability (Lin and Lee, 2004).

Table 5

Relationship between Variable Components of Moral Reasoning, AVE and CR

\begin{tabular}{lccccc}
\hline Variable & $\begin{array}{c}\text { Moral } \\
\text { decoupling }\end{array}$ & $\begin{array}{c}\text { Moral } \\
\text { rationalization }\end{array}$ & $\begin{array}{c}\text { Moral } \\
\text { coupling }\end{array}$ & AVE & CR \\
\hline Moral decoupling & 1 & - & - & 0.65 & 0.85 \\
Moral rationalization & $0.58(10.16)$ & 1 & - & 0.46 & 0.81 \\
Moral coupling & $-0.28(-3.60)$ & $-0.11(-1.36)$ & 1 & 0.60 & 0.75 \\
\hline
\end{tabular}

Source: Authors.

The numbers outside the parenthesis are the correlation between variables, and the numbers in parentheses are T-VALUE of them.

\section{Discussion and conclusion}

Due to the increase in research on consumer behavior and the lack of a rich and appropriate research background to determine the relationship between these subscales and consumer behavior in sports, It is important to have an appropriate and credible measurement tool to examine consumer moral reasoning that are reasonably reliable; Therefore, the purpose of this study was to develop a scale for measuring consumer moral reasoning in sports marketing that has reliable and valid indicators and components. Given that the basis of any research is the use of valid and reliable tools and the interpretation of research results depends on the validity of the tools used, researchers must be sure of the validity of the tools (Burns and Grove, 1999). According to Barbara and William (2005), in confirmatory factor analysis, 
certain theoretical models are compared and, in fact, it is a useful and useful way to review the appropriate tools for conducting research. In this study, experts were used to determine the face and content validity related to the tools extracted from the qualitative part of the research, as well as the use of Bhattacharjee, Berman \& Reed (2013) tools, whose items were translated into Persian. Finally, after making the proposed corrections, the final questionnaire was prepared. Formally, there was no significant problem in this questionnaire and the sample group did not have a major problem in understanding the questions and the meaning of the questions was clear to them.

As it is evident, by transgressions or scandals of public figures, consumers who have developed emotional attachment toward them (Thomson 2006) and their associated brands (Thomson, MacInnis, and Park 2005) will experience a dilemma. Previous studies have acknowledged that this stage of the problem can be understood by applying the theory of social psychology and cognitive dissonance. Cognitive dissonance theory says that people experience discomfort when they have two or more conflicting perceptions such as beliefs, ideas, and emotional responses (Festinger, 1957). According to Festinger, people in an inconsistent state experience an imbalance such as shy, frustration, anger, hunger, fear, guilt and anxiety as evidence of this state. According to the negative emotional responses of consumers to collective moral misconduct, a study (Grappi, Romani and Bagozzi, 2013) has shown that consumers tend to experience an unstable feeling in dealing with negative promotions related to the organization commercial behavior that the negative moral emotions (e.g., humiliation, anger and disgust) are its sign. In addition, regarding the endorsement of the athlete, Customers who are interested in prominent athletic figures can experience this stage when confronted with conflicting information with previous positive feelings about the athlete.

On the other hand, people tend to maintain a positive perception of their popular public images. However, since individuals usually want to be considered moral entities, they often tend to reject immoral behaviors that conflict with their moral standards (Bandura, 1991; Baumeister, 1998). This means that when sports customers are informed of the immoral behavior of their favorite endorser athlete; only maintain the positive perceptions of offending athlete which could harm their moral standards. Thus, researchers acknowledge that transgressions by public figures lead to cognitive tensions related to the preservation or rejection of one's moral standards (e.g., Aronson 1969; Festinger 1957). In order to cope with this unpleasant situation, Individuals activate specific psychological reasoning responses. 
Moral reasoning literature has proposed two concepts for describing these complex moral reasoning processes: moral rationalization and moral decoupling.

By reconstruing transgressions so that immorality is justified, excused, or otherwise reduced, consumers can reduce the tension between desired outcomes and their moral standards (Bandura, 1991; Ditto, Pizarro, \& Tannenbaum, 2009; Tsang, 2002). Among the theoretical approaches consistent with moral rationalization, the literature in moral disengagement presents the most complete and well-developed theory of moral rationalization (Tsang, 2002).

Moral disengagement is a self-regulatory process of employing reasoning strategies that justify or excuse immoral actions in order to make them personally acceptable (Bandura, 1991, 1999; Bandura et al., 1996). In other words, this means that individuals by distinguishing moral judgments from immoral occurrences convinced themselves for not using their moral standards in certain situations. Bandura and colleagues refer to these strategies as mechanisms of moral disengagement and group them in broad categories, including (1) redefining harmful conduct, (2) minimizing a perpetrator's role in causing harm, (3) minimizing or distorting harm caused by a perpetrator, and (4) dehumanizing or blaming the victim (Bandura, 1991; Bandura et al., 1996).

The moral decoupling strategy in comparison to rationalization strategy enables consumers to support and admire the performance of an immoral actor without being subject to self-reproach (Bhattacharjee, Berman \& Reed, 2013). Bhattacharjee, Berman \& Reed (2013), determined the moral decoupling argument and tested the role of the reasoning strategy systematically. They found in part of their studies that moral decoupling is a distinct argumentative strategy that allows consumers to continue to support a transgressor's performance while simultaneously condemning his or her transgressions. Of course, that study did not find that moral decoupling is not easier to justify than moral rationalization. In other words, consumers are not compelled to tolerate the risk of violating their moral standards or being evaluated negatively by others because of dissociates judgments of performance from judgments of morality. Previous studies of cognitive dissonance identified various types of evidence, including function performance, physiological arousal, and negative effects (Elliot \& Devine, 1994; Harmon-Jones, 2000; Kidd \& Berkowitz, 1976; Losch \& Cacioppo, 1990; Martinie, et al., 2013; Rhodewalt \& Comer, 1979; Zanna \& Cooper, 1974). Festinger (1957) also acknowledged that cognitive dissonance leads to unpleasant feelings. 
According to the findings of the present study, any violation of doping rules is rejected by the interviewees. Findings from other studies also showed that consumers do not tolerate doping. A large number of them were interested in and in favor of reacting badly to doped athletes (Solberg, Hanstad, Thöring, 2010; Stamm, et al., 2008; Moston, Skinner, Engelberg, 2012; Reeth \& Lagae, 2013). Also, Till and Shimp (1998) found that negative publicity related to athlete violation had a negative effect on consumer ratings of an endorsed brand. Although these can be modified by variables and have a significant impact on moral reasoning strategies, given the consumer moral reasoning processes, it is well documented that cognitive dissonance occurs when consumers have non-aligned cognitions simultaneously: Positive about the athlete and negative perceptions about the athlete committing a moral violation (Festinger, 1957). Consumers are motivated to come to terms with this imbalance by activating different paths of moral reasoning. For example, the literature has shown that individuals are often inclined to activate moral decoupling strategies (moral rationalization; Bandura, 1991) or to separate moral judgments from performance judgments (moral decoupling; Bhattacharjee, Berman \& Reed, 2013) have. These ethical decoupling processes help consumers to be more generous and to show their support for athletes who commit immorality (Lee, 2015). Therefore, according to the factors discovered in the qualitative stage of the research, it can be concluded that consumers who suffer less negative consequences can be due to cognitive dissonance and the use of moral reasoning in them.

In the qualitative findings section of the present study, most of the interviewees who were opposed to doping and expressed negative feelings about it experienced cognitive dissonance in the face of doping athlete status and used moral reasoning strategies to justify or moderate attitudes.

Given these biased psychological processes, it has become apparent that highly identifiable consumers often tend to resist negative information (e.g., violations) and support their own acclaimed endorsed celebrities. For example, a Tiger Woods fan, despite the golfer's marital corruption, showed support for stability and commented on his website, "I have been a fan of you and I will be a fan of you because I believe you are a great athlete in golf' (Wheeler, 2009). This example shows how sports fans place more emphasis on the sports performance of the offending golfer than his immorality, as theories of moral separation suggest. Resistance to anti-attitudinal information derived from their identities activates the moral reasoning processes of disconnection, such as moral decoupling (MD) or moral rationalization (MR). From a moral coupling (MC) point of view, if sports fans find too much of an identity with an athlete, the fan 
will become more defensive in order to maintain their previous attitudes, and ultimately using the MC strategy Which can destroy his perception of the athlete, they will be less aroused.

However, a recent study done by (Bhattacharjee, Berman \& Reed, 2013) broadened one person's moral reasoning processes in relation to other people's immoral actions. When considering celebrity misconduct, that study specifically acknowledged that consumers often find celebrity immoral judgments irrelevant and separate from professional performance judgments (so-called moral decoupling). This provides an appropriate theoretical framework for explaining how individuals support stained public images simultaneously with two types of conflicting perceptions (positive for performance judgment versus negative for moral judgment).

Violations of endorsement athlete are considered immoral not only by consumers who have developed a deep emotional attachment to the athlete but also by other consumers who are indifferent to them. In the light of the theory of moral psychology, moral feelings occur directly and spontaneously, and moral reasoning seeks to construct moral reasons (Haidt, 2001). Also, according to Kunda (1990), people tend to choose information and try to get their own moral conclusion. The body of literature on this subject, including the research of Bhattacharjee, Berman \& Reed (2013) with the focus on moral decoupling and Bandura, et al. (1996) with the focus on moral rationalization have provided a useful theoretical framework to explain the mechanisms of moral reasoning. This literature in particular suggests that cognitive dissonance motivate individuals to activate their moral reasoning strategies.

The quantitative findings of this study shows that the validity and reliability of the measuring model of the consumer moral reasoning facing the scandal of doping sporting endorsement received acceptable values in comparison with reported values in other studies (e.g. Bhattacharjee, Berman \& Reed, 2013). Cronbach's alpha coefficients were found to be very good for variables of moral decoupling (0.842), moral coupling (0.749), and moral rationallization (0.842). The findings of the confirmatory factor analysis and its related indicators, including indicators of goodness and badness, all indicate that the values are standardized. The results of the measurement model of moral reasoning components in the standard estimation, significant coefficients and obtained parameters from model showed good fit of the model which coincided with the findings of Bhattacharjee, Berman \& Reed (2013). According to the LISREL output, the values of RMSEA, AGFI, GFI and NFI represent a very good fit. Also, all factor loads are greater than 0.5 and, secondly, the average variance extracted 
Manouchehri, J., \& Soheili, B. (2021, set./dez.). Measuring model of consumer's moral reasoning in sport marketing: a scale development

(AVE) in the variables of moral decoupling and moral coupling indicated convergent type of validity. Also, the average variance extracted (AVE) in all variables indicated discriminant type of validity. The composite reliability (CR) in all variables also indicated composite type of reliability. Regarding both qualitative and quantitatve findings the below model is the final proposed one as the measuring model of consumer's moral reasoning in sport marketing (CMRM) which is rooted in the cognitive dissonance theory (Figure 2).

Figure 2

Measuring Model of Consumer's Moral Reasoning in Sport Marketing (CMRM)

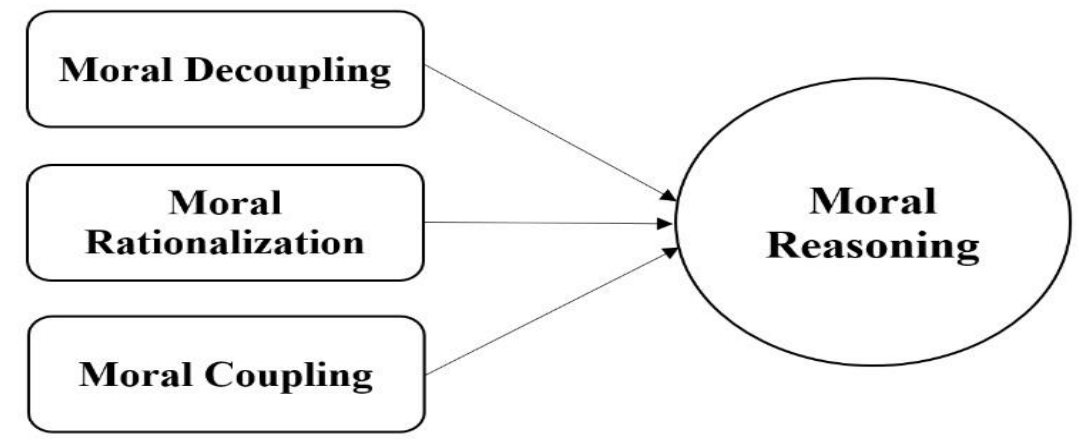

Source: Authors.

Finally, the moral reasoning resulting from cognitive dissonance in the individual may cope with conflicting attitudes in a different way. The present study sheds light on the fact that people who oppose doping may at times tend to support the doped athlete and purchase the product under his or her advertising with certain moral reasoning. The research literature also confirms the existence of moral reasoning resulting from contradictory attitudes or cognitive dissonance. Previous findings have shown that in the case of public image violations, moral decoupling can predict consumer support and non-support more than moral rationalization (Bhattacharjee, Berman \& Reed, 2013). Moral coupling is also common and has a unique predictive application in describing consumer assessment of abuse. Findings also showed that the immoral behavior of public images and the expansion to a wider brand are conditioned by the choices of consumers' moral reasoning (Lee \& Kwak, 2015). Therefore, the present finding that the rationalizing effect of moral rationalization is consistent with previous findings that consumers adjust negative information about the athlete when making a purchase decision (Bhattacharjee, Berman \& Reed, 2013; Lee \& Kwak, 2015; Bednall \& Collings, 2000; Matos 
\& Veiga, 2005; Funk \& Pritchard, 2006; Kwak, Kim, Zimmerman, 2010; Lohneiss \& Hill, 2014; Um, 2013).

Due to the often negative view toward doped athlete prior to ethical reasoning, it is suggested that endorsement contracts be more stringent by companies and it seems more sensible to use sports celebrities where the number of their positive doping tests is lower and there is little chance of such a violation and it seems more sensible to use sports celebrities where the number of their positive doping tests is lower and there is little chance of such a violation. It is also suggested that athletes who are close to the championship retirement age and are popular and trusted in the community and are less likely to take doping risk should be given priority for endorsement activities. Some of the qualitative findings of the research showed that the quality of the product may make the consumer less focused on the doping violation of the endorsed athlete. Therefore, it is suggested that future researchers consider the strength of the brand and its popularity with the consumer as a moderating factor during negative advertising and behavioral consequences. Finally, it is suggested that a similar study be conducted to investigate the moral reasoning of the general public after committing doping by an endorsed athlete in order to develop knowledge in this field.

In the present research, the individual differences among respondents, such as cultural, social, personality and livelihood, in how to respond to questions can be considered as a limitation. Therefore, considering the different perceptions of the sports community and the general population about doping or any violation, the study of the differences can be of interest to future researchers. The present study was limited to doping violation of endorser athletes and it is necessary that other violations (e.g., illegal relationships, collusion as a result of the race, theft, beating, murder, etc.) that lead to negative propaganda and affect consumer moral reasoning, as an interesting study subject be considered by other researchers. Moreover, due to the often negative view toward doped athlete prior to moral reasoning, it is suggested that endorsement contracts be more stringent by companies and it seems more sensible to use celebrities from sports where the number of their positive doping tests is lower and there is little chance of such a violation. It is also suggested that athletes who are close to the championship retirement age and are popular and trusted in the community and are less likely to take doping risk should be given priority for endorsement activities. Some of the qualitative findings of the research showed that the quality of the product may make the consumer less focused on the doping violation of the endorsed athlete. Therefore, it is suggested that future researchers 
Manouchehri, J., \& Soheili, B. (2021, set./dez.). Measuring model of consumer's moral reasoning in sport marketing: a scale development

consider the strength of the brand and its popularity with the consumer as a moderating factor during negative advertising and behavioral consequences. Finally, it is suggested that a similar study be conducted to investigate the moral reasoning of the general public (not athletes' community) after committing doping by an endorsed athlete in order to develop knowledge in this field.

\section{References}

Aronson, E. (1969). The theory of cognitive dissonance: A current perspective. In L. Berkowitz (Ed.), Advances in Experimental Social Psychology (Vol. 4). New York: Academic Press, https://doi.org/10.1016/S0065-2601(08)60075-1

Barbara, H. M., \& William, F. (2005). Statistical methods for health care research. London: Lippincott Williams and Wilkins.

Barkoukis, V., Kartali, K., Lazuras, L., Tsorbatzoudis, H. (2016). Evaluation of an antidoping intervention for adolescents: Findings from a school-based study. Sport Management Review, 19(1): 23-34, https://doi.org/10.1016/j.smr.2015.12.003

Bandura, A. (1991). Social Cognitive Theory of Moral Thought and Action. In W. M. Kurtines \& J. L. Gewirtz (Eds.), Handbook of moral behavior and development: Theory, research, and qpplications (Vol. 1), Hillsdale, NJ: Erlbaum.

Bandura, A. (1999). Moral disengagement in the perpetration of inhumanities. Personality and Social Psychology Review, 3(3), 193-209, https://doi.org/10.1207\%2Fs15327957pspr0303_3

Bandura, A., Barbaranelli, C., Caprara, G. V., \& Pastorelli, C. (1996). Mechanisms of moral disengagement in the exercise of moral agency. Journal of Personality and Social Psychology, 71(2), 364-374, https://psycnet.apa.org/doi/10.1037/0022-3514.71.2.364

Baumeister, R. F. (1998). The self. In D. T. Gilbert, S. T. Fiske, \& G. Lindzey (Eds.), Handbook of social psychology. New York: McGraw-Hill.

Bednall, D. H., \& Collings, A. (2000). Effect of public disgrace on celebrity endorser value. Australasian Marketing Journal, 8(2), 47-57, https://doi.org/10.1016/S14413582(00)70190-X

Bhattacharjee, A., Berman, J. Z., \& Reed, A. II. (2013). Tip of the hat, wag of the finger: How moral decoupling enables consumers to admire and admonish. Journal of Consumer Research, 39(6), 1167-1184, https://doi.org/10.1086/667786

Burns, N., \& Grove. S. K. (1999). Understanding nursing research (2nd edition). Philadelphia. W. B. Saunders Company. 
Manouchehri, J., \& Soheili, B. (2021, set./dez.). Measuring model of consumer's moral reasoning in sport marketing: a scale development

Chin, W.W. (1998). The Partial Least Squares Approach to Structural Equation Modeling. In G.A. Marcoulides (Ed.), Modern Methods for Business Research, Lawrence Erlbaum Associates: Mahwah, NJ, 295-336.

Clark, V.L.P. and Creswell, J.W. (2008). The Mixed Methods Reader. Sage Publication: $1^{\text {st }}$ Edition.

Copeland, R. and Potwarka, L.R. (2021). Individual and contextual factors in ethical decision making: A case study of the most significant doping scandal in Canadian university sports history. Sport Management Review, 19(1): 61-68, http://dx.doi.org/10.1016/j.smr.2015.08.004

Danaeifar, H., Alvani, S.M., and Azar, A. (2013). Qualitative research methodology in management: a comprehensive approach. Second edition, Eshraghi Safaar publication.

Ditto, P.H., Pizarro, D.A., \& Tannenbaum, D. (2009). Motivated moral reasoning. In D. M. Bartels, C. W. Bauman, L. J. Skitka, \& D. L. Medin (Eds.), Moral cognition and decision making. San Diego: Elsevier.

Elliot, A.J., \& Devine, P.G. (1994). On the motivational nature of cognitive dissonance: Dissonance as psychological discomfort. Journal of Personality and Social Psychology, 67(3), 382-394, https://psycnet.apa.org/doi/10.1037/0022-3514.67.3.382

Festinger, L. (1957). A theory of cognitive dissonance. Stanford, CA: Stanford University Press.

Funk, D.C., \& Pritchard, M.P. (2006). Sport publicity: Commitment's moderation of message effects. Journal of Business Research, 59(5), 613-621, http://dx.doi.org/10.1016/j.jbusres.2005.10.010

Glaser, B. (1992). Basics of grounded theory analysis: Emergence vs forcing. Mill Valley, CA: Sociology Press.

Grappi, S., Romani, S., \& Bagozzi, R.P. (2013) Consumer response to corporate irresponsible behavior: Moral emotions and virtues. Journal of Business Research, 66(10), 18141821, https://doi.org/10.1016/j.jbusres.2013.02.002

Haidt, J. (2001). The emotional dog and its rational tail: A social intuitionist approach to moral judgment. Psychological Review, 108(4), 814-834, https://psycnet.apa.org/doi/10.1037/0033-295X.108.4.814

Harmon-Jones, E. (2000). Cognitive dissonance and experienced negative affect: Evidence that dissonance increases experienced negative affect even in the absence of aversive consequences. Personality and Social Psychology Bulletin, 26(12), 1490-1501, https://doi.org/10.1177\%2F01461672002612004 
Manouchehri, J., \& Soheili, B. (2021, set./dez.). Measuring model of consumer's moral reasoning in sport marketing: a scale development

Houlihan, B. (2002). Dying to Win: Doping in Sport and the Development of Anti-doping Policy. Strasbourg: Council of Europe Publishing, 2002.

Hur, Y.; Lim, C.H.; Won, D.C.; Kwon, S.Y. (2018). Types of Brand Transgressions and Consumers' Moral Reasoning Strategies on an Endorser. Sport Marketing Quarterly, 27, 275-286, http://dx.doi.org/10.32731/SMQ.274.122018.06

Kidd, R. F., \& Berkowitz, L. (1976). Effect of dissonance arousal on helpfulness. Journal of Personality and Social Psychology, 33(5), 613-622, https://psycnet.apa.org/doi/10.1037/0022-3514.33.5.613

Kotler, P., and Armstrong, G. (2012). Marketing Principles. Treanslated in Persian by Saadi, M.R., and Saleh Ardestani, A., Aylar Publication, $1^{\text {st }}$ edition, p 25-26.

Kunda, Z. (1990). The case for motivated reasoning. Psychological Bulletin, 108(3), 480-498, https://psycnet.apa.org/doi/10.1037/0033-2909.108.3.480 .

Kwak, D. H., Kim, Y. K., \& Zimmerman, M. H. (2010). User-versus mainstream-mediagenerated content: Media source, message valence, and team identification and sport consumers' response. International Journal of Sport Communication, 3(4), 402-421, https://doi.org/10.1123/ijsc.3.4.402

Lee, J.S. (2015). Athlete Endorser's Transgression and Sport Consumer's Moral Reasoning Strategy: Moral Coupling and Boundary Conditions. A PhD dissertation submitted in partial fulfillment of the requirements for the degree of Doctor of Philosophy (Kinesiology), University of Michigan.

Lee, J. S., \& Kwak, D. H. (2015). Consumers' responses to public figures' transgression: Moral reasoning strategies and implications for endorsed brands. Journal of Business Ethics, https://doi.org/10.1007/s10551-015-2544-1

Lin, H.F., \& Lee, G.G. (2004). Perceptions of senior managers toward knowledge-sharing behavior. Management Decision, 42(1), 108-125, https://doi.org/10.1108/00251740410510181

Lohneiss, A., \& Hill, B. (2014). The impact of processing athlete transgressions on brand image and purchase intent. European Sport Management Quarterly, 14(2), 171-193, https://doi.org/10.1080/16184742.2013.838282

Losch, M. E., \& Cacioppo, J. T. (1990). Cognitive dissonance may enhance sympathetic tonus, but attitudes are changed to reduce negative affect rather than arousal. Journal of Experimental Social Psychology, 26(4), 289-304, https://psycnet.apa.org/doi/10.1016/0022-1031(90)90040-S

Manouchehri, J. (2019). Measuring Model of Consumer's Moral Emotions in Sport Marketing: A Scale Development. Journal of Marketing Management, 43: 75-89.

Manouchehri, J. (2021). The Consequences of Endorser's Doping Scandal in Sport Marketing. Sport Management Studies, https://dx.doi.org/10.22089/smrj.2019.6875.2438 
Manouchehri, J., \& Soheili, B. (2021, set./dez.). Measuring model of consumer's moral reasoning in sport marketing: a scale development

Manouchehri, J., Hamidi, M., Sajadi, S.N., \& Honari, H. (2021). Designing a Qualitative Model of Doping Phenomenon Effect on Sport Marketing in Iran. Sport Management, 0(0): 000-000. (In Publishing).

Manouchehri. J. and Tojari, F. (2014). Foundamental of Doping Psychology in Sport. Hatmi Publication in cooperation with the Sport and Youth Ministry of Iran, 10-14.

Martinie, M. A., Olive, T., Milland, L., Joule, R. V., \& Capa, R. L. (2013). Evidence that dissonance arousal is initially undifferentiated and only later labeled as negative. Journal of Experimental Social Psychology, 49(4), 767-770, https://doi.org/10.1016/j.jesp.2013.03.003

Matos, C.A., and Veiga, R.T. (2005). How to Deal with Negative Publicity: the Importance of Consumer Involvement. Brazilian Administration Review, 2 (1): 57-72, https://doi.org/10.1590/S1807-76922005000100005

Moston, S., Skinner, J. \& Engelberg, T. (2012). Perceived incidence of drug use in Australian sport: a survey of public opinion. Sport in Society, 15 (1), 64-77, https://doi.org/10.1080/03031853.2011.625277

Newman, K.P.; Brucks, M. (2018). The influence of corporate social responsibility efforts on the moral behavior of high self-brand overlap consumers. Journal of Consumer Psychology, 28, 253-271, https://doi.org/10.1002/jcpy.1027

Overbye, M. (2016). Doping control in sport: An investigation of how elite athletes perceive and trust the functioning of the doping testing system in their sport. Sport Management Review, 19(1): 6-22, http://dx.doi.org/10.1016/j.smr.2015.10.002

Paharia, N., Vohs, K. D., \& Deshpande, R. (2013). Sweatshop labor is wrong unless the shoes are cute: Cognition can both help and hurt moral motivated reasoning. Organizational Behavior and Human Decision Processes, 121, 81-88, https://doi.org/10.1016/j.obhdp.2013.01.001

Perron, L. (2009, June 6). Should NFL give Vick a second chance? Reuter. Retrieved from http://blogs.reuters.com/sport/2009/06/06/should-nfl-give-vick-a-secondchance/?cp=all\#comments

Reeth, D.V., \& Lagae, W. (2013). Public opinion on doping in cycling: differences among population groups. Faculteit Economie en Bedrijfswetenschappen Campus Brussel (Hubrussel).

Rhodewalt, F., \& Comer, R. (1979). Induced-compliance attitude change: Once more with feeling. Journal of Experimental Social Psychology, 15(1), 35-47, https://doi.org/10.1016/0022-1031(79)90016-7 
Manouchehri, J., \& Soheili, B. (2021, set./dez.). Measuring model of consumer's moral reasoning in sport marketing: a scale development

Soheili, B., \& Manoucehri, J. (2020). Predicting Spectators' Involvement in Professional Football: The Role of Core Product Quality and Service Quality. Sport Management Studies, 12(60): 217-36, https://dx.doi.org/10.22089/smrj.2019.6888.2445

Solberg, H.A., Hanstad, D.V., \& Thöring, T.A. (2010). Doping in elite sport, do the fans care? Public opinion on the consequences of doping scandals. International Journal of Sports Marketing \& Sponsorship, 11 (3), 185-199, https://doi.org/10.1108/IJSMS-1103-2010-B002

Stamm, H., Lamprecht, M., Kamber, M., Marti, B. \& Mahler, N. (2008). The public perception of doping in sport in Switzerland, 1995-2004. Journal of Sports Sciences, 26 (3), 235-242, https://doi.org/10.1080/02640410701552914

Straub, D.W. (1989). Validating instruments in MIS research. MIS Quarterly, 13(2), 147-69, https://doi.org/10.2307/248922

Strauss, A., Corbin, J. (1992). Basics of Qualitative Research: Techniques and Procedures for Developing Grounded Theory. Journal of Marketing Research, 29(3): 382-384.

Tashakkori, A. and Creswell, J.W. (2007). The New Era of Mixed Methods. Journal of Mixed Methods Research, 1:3, https://doi.org/10.1177/2345678906293042

Till, B. D., \& Shimp, T. A. (1998). Endorsers in advertising: The case of negative celebrity information. Journal of Advertising, 27(1), 67-82, https://doi.org/10.1080/00913367.1998.10673543

Thomson, M. (2006). Human brands: Investigating antecedents to consumers' strong attachments to celebrities. Journal of Marketing, 70(3), 104-119, https://doi.org/10.1509\%2Fjmkg.70.3.104

Thomson, M., MacInnis, D. J., \& Park, C. H. (2005). The ties that bind: Measuring the strength of consumers' emotional attachments to brands. Journal of Consumer Psychology, 15(1), 77-91, https://doi.org/10.1207/s15327663jcp1501_10

Tsang, J. (2002). Moral rationalization and the integration of situational factors and psychological processes in immoral behavior. Review of General Psychology, 6(1), 25-50, https://doi.org/10.1037\%2F1089-2680.6.1.25

Um, N. (2013). Celebrity scandal fallout: How attribution style can protect the sponsor. Psychology \& Marketing, 30(6), 529-541, https://doi.org/10.1002/mar.20625

Von Schuckmann, J., Barros, L.S.G., Dias, R.S., Andrade, E.B. (2018). From slum tourism to smiley selfies: The role of social identity strength in the consumption of morally ambiguous experiences. Journal of Consumer Psychology, 28, 192-210, https://doi.org/10.1002/jcpy.1016

Wheeler, K. (2009, December 9). Tiger Woods scandal update: Fans on Woods' website leave comments of disapproval, support for Elin. Examiner.com. Retrieved from http://www.examiner.com/article/tiger-woods-scandal-update-fans-on-woods-websiteleave-comments-of-disapproval-support-for-elin 
Manouchehri, J., \& Soheili, B. (2021, set./dez.). Measuring model of consumer's moral reasoning in sport marketing: a scale development

Zanna, M. P., \& Cooper, J. (1974). Dissonance and the pill: An attribution approach to studying the arousal properties of dissonance. Journal of Personality and Social Psychology, 29(5), 703-709, https://psycnet.apa.org/doi/10.1037/h0036651

\section{Appendix}

\section{Qualitative research questionnaire}

\section{Part 1: Research Scenario}

Babak is your favorite athlete and 26-year-old weightlifter who won a gold medal at the Rio Olympics. He has won gold medals at the recent World Championships and also won the quota for the Tokyo Olympics, and has previously won gold medals in 2 World Championships and 4 National Championships. He has already signed a four-year sponsorship agreement (using Babak's photo next to Hype soft drinks in billboards and other media) with the Hype Energy Drink brand (assuming this is your favorite brand as well). But a month ago, the National AntiDoping Organoization (NADO) of Iran announced and applied a 4-year ban by the World AntiDoping Agency (WADA) due to his positive doping test. This means that he will be deprived of the world championship medal and will be banned from attending official events for four years. According to the WADA, he has used anabolic steroids.

\section{Part 2: Demographic questions}

1. In what sport or sports are you active and under what title (athlete, coach, referee, manager, spectator, and fan) do you work?

2. How many years of sports experience do you have?

3. If you have a brilliant track record in sports, name the most important ones.

4. What is your age and level of education?

\section{Part 3: The main research questions}

5. What did you think of the athlete's reputation before committing doping?

6 . What do you think about the image of the mentioned athlete after committing doping?

7. How important is it for you to be a fan of that athlete?

8. How committed are you to that athlete?

9. What effect does this violation have on your assessment of ethical issues and his successes?

10. In your opinion, what is the extent of the loss of the mentioned action in comparison with other social issues or other athletes, and what reasons can there be for this commission? 
Manouchehri, J., \& Soheili, B. (2021, set./dez.). Measuring model of consumer's moral reasoning in sport marketing: a scale development

11. Should this violation affect people's assessment of him?

12. How likely is it that you will buy an athlete-endorsed product?

13. How supportive and committed are you to that athlete?

14. How important is the success of this athlete to you?

15. Can the opinion of friends or committing a violation of the mentioned athlete affect your support for him?

16. Do you feel good about buying the product? (Before and after doping)

17. Will you buy the product again? (Before and after doping)

18. What do you think about the product that the doped athlete promotes?

Part 4: Free time to provide feedback to the subject

19. In general, express your opinion about doping and explain the issues that were not mentioned in the discussion and you consider them important issues and factors in sports marketing. 